\title{
Making the National Security and Resilience as Commander of the Constitutional Court
}

\author{
Nando Yussele Mardika ${ }^{1}$, Margaretha Hanita ${ }^{2}$ \\ \{Mardikanando@gmail.com ${ }^{1}$, Margaretha.hanita@gmail.com² \\ ${ }^{1,2}$ National Resilience Studies, School of Strategic and Global Studies, Universitas Indonesia
}

\begin{abstract}
The national security and resilience is an essential concept in bringing the country of Indonesia forward, with globalization and technological development. Many defences and security threats are coming, especially on the internal nation, asymmetric warfare will be very dangerous. It can divide the if not immediately overcome, so that the concept of national defense and security becomes critical, because for the realization of a safe and comfortable safe state, the situation will be achieved if Indonesian democracy is the rule of law in accordance with article 1 paragraph (1) of the 1945 Constitution has been implemented properly. The relation between national security and resilience as the ideals of the nation originates from the Indonesian constitution as a derivative of the values of Pancasila which is the legal basis in Indonesia, so that constitutional awareness is essential so that people know their rights and obligations, in order to achieve conditions that are in accordance with destination of the country of Indonesia.
\end{abstract}

Keywords: Resilience, Law, Constitutional Court, Commander

\section{Introduction}

Firstly, the writer will explain the position of perspective adopted, this paper used national resilience perspective as a concept. National Resilience is one of the typical conceptions of Indonesia in the form of conceptual teachings on regulation in the administration of the state. Every nation aspires, one of Indonesian nation goal is the achievement of national security. Resilience and security national is an important domain to attain the objectives of the Indonesian state in accordance with the Preamble Constitution of 1945 (UUD 1945) fourth paragraph, goal of state as follow:

"shall protect the whole people of Indonesia and the entire homeland of Indonesia, and in order to advance general prosperity, to develop the nation's intellectual life, and to contribute to the implementation of a world order based on freedom"'

As the Rechtsstaat has an objective and spirit to achieve national interests, Indonesia insert national security in the Constitution on Article 30 Paragraph (1) and (2), the point is responsibility for defense and security, all the people of Indonesia are entitled and obliged to participate in keep national defense and security, the military and police agencies as the vanguard and the entire Indonesian community as the supporting force. ${ }^{2}$ From Article 30

\footnotetext{
${ }^{1}$ Fourth paragraph of preamble of the 1945 Constitution

${ }^{2}$ See Article 30 paragraph (1) and (2) of the 1945 Constitution
} 
paragraph (2) it can be interpreted that those responsible for maintaining the defense and security of the State are not only the military and but also all Indonesian people.

There are two scope of defense and security, ${ }^{3}$ the first is strategy (Military), its means that national resilience related to state sovereignty (regional security and war) and nonstrategy (non-military) is based on the internal state of country which is affected by economic stability, political, cultural, and social. ${ }^{4}$ Nasional Resilience of the non-military context is the national power development through the regulation and implementation of welfare and security are harmonious, in all aspects of life as a whole, comprehensive, and integrated based on Pancasila and the 1945 Constitution. ${ }^{5}$ In other words, the national resilience conception is a guideline (tool) to improve enhance (method) diligence and strength of the nation.

As a concept, national security and resilience achieving ideal goals in society, so, it should have a guardian / commander to enforce it, especially about the constitution awareness, institutions that provide enlightenment to the community and as the main reference in the disturbance situation. The constitutional court as an official government that has the authority to conduct a judicial review of law to the 1945 Constitution (The guardian of the constitution), which aims to enforce the Constitution so that the creation of laws that provide expedience, certainty and justice to the public. ${ }^{6}$ In line to the concept of resilience and security which aims to create safe, comfortable and peaceful.

In contrast to the Indonesian National Military and The Indonesian National Police is described in article 30 paragraph (2) of the 1945 Constitution that the Military and Police are instruments of the executive body, the Military 's authority in accordance with law 24 of 2004 of the Indonesian National Military 's functions as a tool of state defense and functions as a deterrent to any forms of military threats and armed threats from domestic and foreign against the sovereignty, territorial integrity, and nation safety. ${ }^{7}$ While the functions of the Indonesian National Police are the main tasks of the Indonesian National Police to maintaining security and public order; enforcing the law; and provide protection, and service to the community. ${ }^{8}$ From the explanation of the Indonesian National Military and The Indonesian National Police's function, only these two institutions have more technical authority, namely is protect by using direct-action.

This paper will discuss national security and resilience in a non-strategic (nonmilitary) context. National security and resilience is not only a domain of the state apparatus of executive institutions that have an executorial function (the Indonesian National Military and The Indonesian National Police), but also duty of all Indonesian people, and The Constitutional Court as an institution (The guardian of the constitution) has consistently enlighten people.

\footnotetext{
${ }^{3}$ National Security Concept and Security Systems To Indonesia (Jakarta: Secretariat of the National Security Council, 2010), p vi

4 Hermann, Charles; “Are The Dimensions And Implications Of National Security Changing (Mershon Center Quaterly Report 3, No. 1 Autumn, 1977), p.5-7.

${ }^{5}$ Op.Cit. Naational Security, p vii

${ }^{6}$ Op.Cit. Naational Security, p vi

${ }^{7}$ Article 6 Paragraph (1) of Law Number 32 Year 2004 on the Indonesian National Military

${ }^{8}$ Article 13 of Law No. 2 of 2002 on the Indonesian National Police of the Republic of Indonesia
} 


\section{Discussion}

\subsection{The National Security and Resilience as a Concept}

The concept of National Resilience is a doctrine that is believed by all Indonesian people as well as best way that needs to be implemented in the national life.9 National Resilience concept is a conceptual base based on Pancasila and the 1945 Constitution as an ideal and constitutional base.10 Whereas national security is a goal, national security that can be interpreted as both a condition and a function, in other word, there is a safe, comfortable and peaceful state, this kind of security condition is a basic human need besides welfare.11

In the development of national resilience theory according to Berkowitz is defined as the ability of a nation to protect its internal values from external threats. 12 To achieve national security which is under threat from outside it requires military force. 13 But the concept of resilience has shifted due to the inclusion of globalization, which has brought democratic values and human rights to the point of raising awareness. The security sector is no longer seen as a just military domain but has become a universal multisector domain to save humanity from the war threats among countries, civil war, ethnic cleansing, communal conflict, and various other physical and non-physical threats that endanger the lives and humanity life.14

Understanding security and resilience is more interpreted as a way to prosperity and security.15 Conceptually, the national resilience of a nation is motivated by:16 (a) What strengths exist in a country and nation so that it is able to preserve the survival of its people, (b) What power should be owned by a country and nation so that it can always maintain its life in the changing times, despite experiencing obstacles, challenges, and threats, (c) Resilience and the ability of a nation to remain victorious, implies order and stability, which have contains the potential for occurring changes. The concept of national resilience also has the principle of Indonesian national resilience based on the values of the Pancasila, the 1945 Constitution and the Archipelago Vision, which consists of:

Principle of Justice and Security Welfare are the two main points in organizing the life of the nation Without these two points, national life will lose their existence relevance. These two points are the principles of the national life system, without them the national life will stop.17 Therefore, welfare and security are intrinsic values in the national life system itself. In national life, the level of welfare and security that has been achieved is a benchmark of national security in general.

The principle of Integral Comprehensiveness of National resilience as a tool and method of achieving and implementing balanced and harmonious welfare and security must be applied in covering the strength of all aspects of social life as a whole, holistically, and integral comprehensive. 18

${ }^{9}$ Opcit, National Security, p vii

${ }^{10} \mathrm{Ibid}, \mathrm{p}$ vii

${ }^{11}$ Ibid.p vii

${ }^{12}$ Berkowitz, Morton, And Bock, PG, Eds. American National Security. (New York: Free Press, 1965), p 23-25

${ }^{13}$ ibid,p 26

${ }^{14}$ Op.cit. National Security. p 1

${ }^{15}$ Sony Soemarsono, Theory of Public Policy: Human Resource Economics (Yogyakarta: Graha Science, 2001), p 106

${ }^{16}$ Ahmad Zubaidi Kaelan, Citizenship Study and Teaching (Yogyakarta: Paradigm, 2007), p 147

${ }^{17}$ Bambang Pranowo, Multidimension of the National Resilience (Jakarta: Pustaka Alvabet 2010), p 18

${ }^{18}$ Ibid, p 23 
The principle of kinship Because in national Resilience the principle of kinship is upheld, the differences and diversity that exist in all parts of Indonesia are recognized. These differences and diversity must be managed and used as wealth and capital Indonesia to develop a sovereign, just and prosperous. In the international context, the principle of kinship means respecting differences to develop harmonious partnership relations does not escalate into conflict.19

The principle of self-awareness to the internal and foreign of national life is a blend of national life interacting. Besides, the national dan state life system greatly affects and interacts with surrounding environment. In these reciprocal interactions often appear positive or negative impacts.20 So, it necessary self-awareness into internal and foreign. 21

self-awareness internal, it means the national resilience must try to look the strengths and weaknesses of the nation itself. In this way, the Indonesian people can measure and improve their national resilience from a lacking aspect.22 it also can cultivate the essence, trait or character, and conditions of national life itself based on proportional values of independent to enhance the independent quality of resilient nation. it does not mean that national resilience contains an isolationism or narrow nationalism (Chauvinism). Meanwhile, selfawareness of foreign, that aims to be able to anticipate the impact of foreign strategic environment and accept the reality of interaction and dependence with the international.23. The national life should be able to develop national power to have an outward impact in the form of deterrence and bargaining power. Interaction with other parties takes precedence in the form of mutually beneficial cooperation

Basically, to achieve national security is divided into two aspects, first is the (Military) strategy and the second is non-strategic (non-military), military threats related to state sovereignty (Regional Security), while non-military threat is socio-cultural because it is internal, or arises from domestic. This type of threat has a socio-cultural dimension because it is driven by issues of poverty, ignorance, backwardness and injustice. These issues are closely related to socio-cultural issues. 24

The effect of technology in this modern era add threat to national security that come from other countries or parties of non-state actors.25 This threat type can be in the form of conventional war which using military force and weapons. But now, we are facing Asymmetric warfare that does not use weapon power. Asymmetric warfare is carried out through culture, financial economics, and information and communication technology. Asymmetric warfare generally aims to spread the doctrine of radical ideology to replace the state ideology with a specific ideology, through violence to spread fear, erode people's trust to the official government, and win the hearts and minds of the people through delegitimation of state.26 Asymmetric warfare is carried out indirectly to influence strengths and exploit the weaknesses of opponents by utilizing technology and public unrest.

\footnotetext{
${ }^{19}$ Ibid, p 25

${ }^{20}$ Dand Hornerr, Strategic Studies in Changing World. (The Australian National University Canberra, 1992), p 16

${ }^{21}$ Ibid, p 17

${ }^{22}$ Wan Usman et al, Resilience of Nation, (Jakarta: National Library, 2003), p 17

${ }^{23}$ Ibid, p 17

${ }^{24}$ Loc.Cit National Security, p Vi

${ }^{25}$ Presented by Nugraha, A \& Loy, N 2013, the Population Development to Strengthen National Security Asymmetric Threats Facing War, (Directorate of Population Impact Analysis, BKKBN, Jakarta, ISBN 978-602-7584-35-8), p 1-2

${ }^{26}$ Ibid, p 3
} 


\subsection{Issues of National Security and Resilience (Non-military)}

In the internal of the Indonesian people, the biggest threat to national security is nonstrategy (non-military) because national security can be realized if the economic, political, social and cultural conditions are well maintained, so that a safe, comfortable and peaceful state is achieved.27

As explained in the previous sub-section on the threat of resilience and security in the form of asymmetric warfare, there are four factors contribute to the magnitude of the potential risk of Asymmetric warfare in Indonesia. First, the social structure, namely the uneven distribution of development in Indonesia. Second, political changes such as democratization, regional autonomy, and region expansion. Third is the fading of the nation's founding values. And fourth, weaknesses in communication and information technology.28

In the current leadership of President Joko Widodo, national security and resilience have become quite complex problems, a lot of turmoil has hit, if we look closely at the uproar that occurs in this nation, giving inconvenience to the community, meaning that conditions of safety, comfort and peace have not yet materialized. Indonesia is a plural popular country where many ethnicities, races and religions live side by side but the harmony between community is plagued by the Islamic radicalism development.

Table 1. The Asymmetric warfare Threat Table ${ }^{29}$

\begin{tabular}{|c|c|c|c|c|c|}
\hline $\begin{array}{c}\text { Subj } \\
\text { ect }\end{array}$ & Target & $\begin{array}{c}\text { Scal } \\
\mathbf{e}\end{array}$ & Method & Motif & Impact \\
\hline $\begin{array}{l}\text { Othe } \\
\mathrm{r} \\
\text { count } \\
\text { ries }\end{array}$ & $\begin{array}{l}\text { Areas and issues } \\
\text { do not yet have } \\
\text { the power of an } \\
\text { international } \\
\text { country, state confid } \\
\text { ential data. }\end{array}$ & $\begin{array}{l}\text { Nati } \\
\text { onal }\end{array}$ & $\begin{array}{l}\text { Ideology } \\
\text { tension, cyberwar }\end{array}$ & $\begin{array}{l}\text { Seizing source } \\
\text { of natural } \\
\text { resources, com } \\
\text { petition econo } \\
\text { mics }\end{array}$ & $\begin{array}{l}\text { Weakening } \\
\text { position } \\
\text { international dipl } \\
\text { omatic failure, } \\
\text { foreign } \\
\text { intervention in } \\
\text { various domestic } \\
\text { policies. }\end{array}$ \\
\hline $\begin{array}{l}\text { Insur } \\
\text { gent } \\
\text { terror } \\
\text { ists / } \\
\text { rebel }\end{array}$ & $\begin{array}{l}\text { Religious } \\
\text { symbols, trade } \\
\text { and tourism centers, } \\
\text { government offices } \\
\text {, young people to be } \\
\text { recruited } \\
\text { as perpetrators. }\end{array}$ & $\begin{array}{l}\text { Cou } \\
\text { ntry } \\
\text { and } \\
\text { Nati } \\
\text { onal }\end{array}$ & $\begin{array}{l}\text { Bomb, } \\
\text { bomb commit suicide, } \\
\text { assault against forces } \\
\text { security }\end{array}$ & $\begin{array}{l}\text { Ideology, viole } \\
\text { nce to gather fi } \\
\text { nancial } \\
\text { resources for ji } \\
\text { had wants } \\
\text { to shape } \\
\text { the country } \\
\text { with their } \\
\text { radical ideolog } \\
y\end{array}$ & $\begin{array}{l}\text { Fear of } \\
\text { the community, } \\
\text { the collapse of } \\
\text { the morale of } \\
\text { the security forc } \\
\text { es due to } \\
\text { being targeted, } \\
\text { security } \\
\text { instability, deteri } \\
\text { orating image } \\
\text { Indonesia. }\end{array}$ \\
\hline
\end{tabular}

${ }^{27}$ Op.cit. National Security.p 1

${ }^{28} \mathrm{Ibid}, \mathrm{p} 2$

${ }^{29}$ Source: Nugraha, A \& Loy, N 2013, the Population Development to Strengthen National Security Threats Facing Asymmetric War, Directorate of Population Impact Analysis, BKKBN, Jakarta, ISBN 978 602-7584-35-8, pp 6-7. 


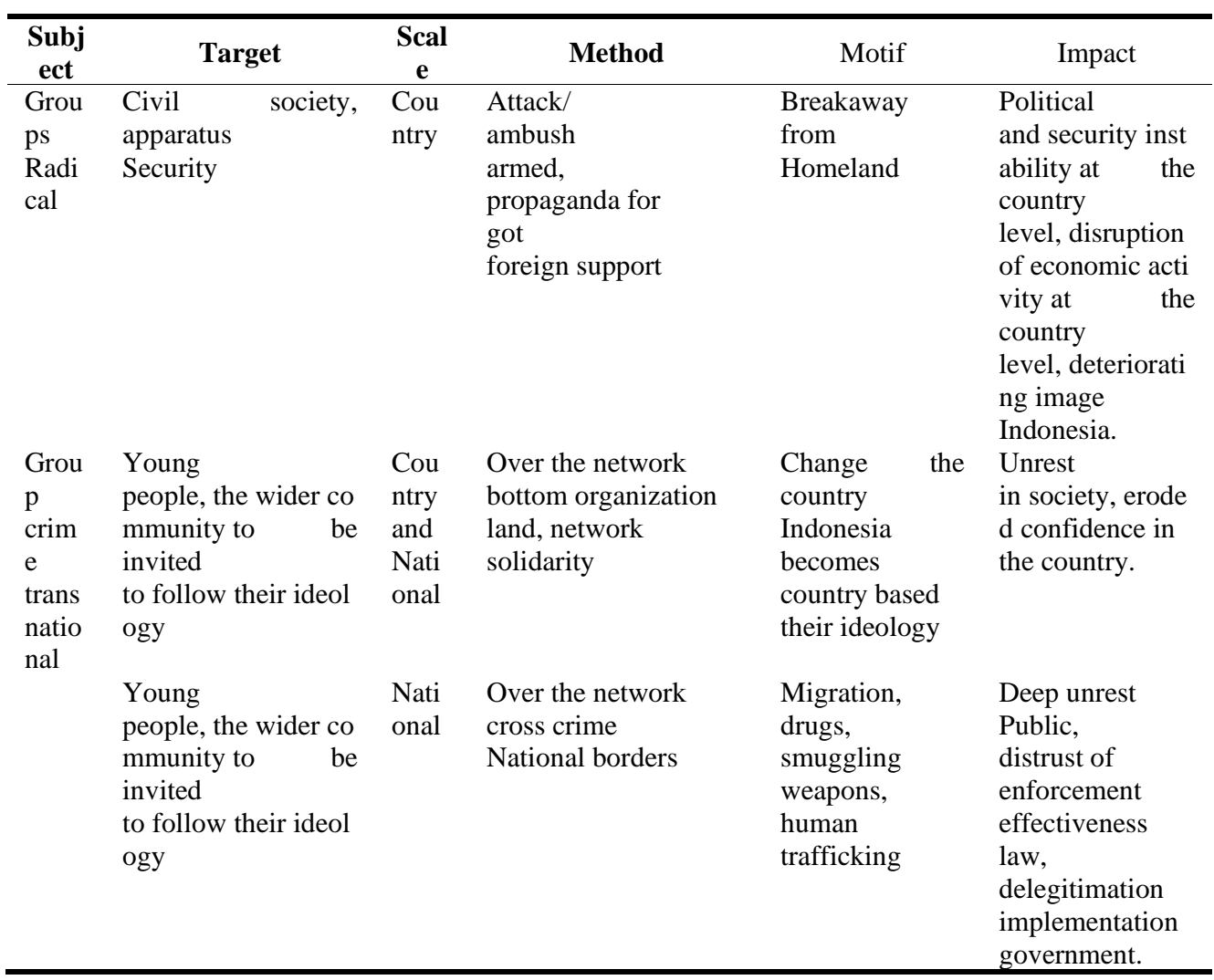

Manifestation from this asymmetric war can be felt when the spread of radicalism such as the ideology of the caliphate, which resulted in uproar public. The threat of asymmetric warfare also impacts on people's behaviour, such as 212 actions and a series of steps with numerical symbols, carrying a large number of masses, then breaking up watching together the G30S / PKI film at Indonesian Legal Aid Foundation (YLBHI). In the threat dimension, the population is seen as a static variable that can be the target group for asymmetric warfare. The community is used as an instrument of asymmetrical warfare by terrorist groups, rebels and transnational organizations to build power against or control the country. This population utilization is influenced by demographic characteristics which include the degree of welfare, level of education, moral strength related to ideological orientation and national affiliation, youth, high mobility, and geographical distribution. ${ }^{30}$

In the resilience dimension, the population is seen as a dynamic variable. Groups of the community of educated, prosperous, and have a strong moral national ideology is the 'forces' cutting edge that can be mobilized to deal with the groups state resistance and other threats from domestic and foreign. This cannot be separated from the problems that cover. Economic, political, social and cultural. Following is an explanation of the threat of resilience from the

${ }^{30}$ Ibid, p 3 
aspect. From a financial standpoint, can realize a financial issue that is not easily swayed by developments in the strategic environment at hand. From a political perspective, can describe the values of the Pancasila and the 1945 Constitution, so to realize a political system that is able to neutralize the negative effects of the strategic environmental influences encountered. In terms of socio-culture, being able to create a social culture that is not easily influenced by adverse cultures that come from foreign.

\subsection{Relations of national security and resilience with the Constitution}

Georg Jellinck argued that creating the law was neither god nor king, but the State. ${ }^{31}$ Jellinck said that law is the embodiment of the will of the State, which means the State has sovereignty in shaping the law ${ }^{32}$. In addition, Sacipto Raharjo asserted that the Law was not only the building of regulations, but also the structure of ideas, culture, and ideals, which meant the law was returned to humans. ${ }^{33}$ Furthermore, Satjipto Raharjo stated that the law needs to return to its fundamental philosophical, namely the code for humans. With these philosophies, human beings become determinants and points of proper orientation. The code is in charge of serving humans, not vice versa. Therefore, the code is not an institution that is free from human interests. The quality of law is determined by its ability to serve social welfare. It has led to progressive law adopting "ideology": Pro-justice law and Pro-people law. ${ }^{34}$

In line with national security and resilience goals, where national resilience is interpreted as a way to prosperity and security. ${ }^{35}$ The aim is to establish a state of safety, comfort, and peace. The concept of national security and resilience also looks at the state of a country, such as the State of Indonesia idea of national resilience is a dilator from: a. what power is in a nation and state so that he is able to maintain the continuity of the State, b. the potential possessed by a nation as a power from within to maintain its survival and fight threats from both internal and foreign, c. the ability of a nation to remain victorious, implies regularity and stability, in which the stability idea of change. ${ }^{36}$

The relation is found in the values of Pancasila as the basic norm or grundnorm, and those values are passed down from Pancasila to the 1945 Constitution and the laws and regulations below, then the National Resilience as a concept to protect the Indonesian people whose values are also taken from Pancasila, and included in the State constitution. Then this relation is actually very close, can be seen in the chart below; ${ }^{37}$

\footnotetext{
${ }^{31}$ H. Abudaud Busaroh. State Science. (Jakarta, Bumi Aksarai 2010). p.19

32 Ibid p 24

${ }^{33}$ Figures series set view article Idonesia Law, Law And Progressife Rahardjo Sacipto Urgency And Critique, (Jakarta: Epistema Institute, 2011), p 15

${ }^{34}$ Ibid, p 24

35 Op.cit. SonySoemarsono, p 106

${ }^{36}$ Op.cit, Wan Usman et al, p 87

37 Nando Yuseele Mardika, National Security and Resilience With the Constitutional Court as a commander, (Submitted On paper KHTN-4, Jember 2017), p 8
} 
Chart 1.

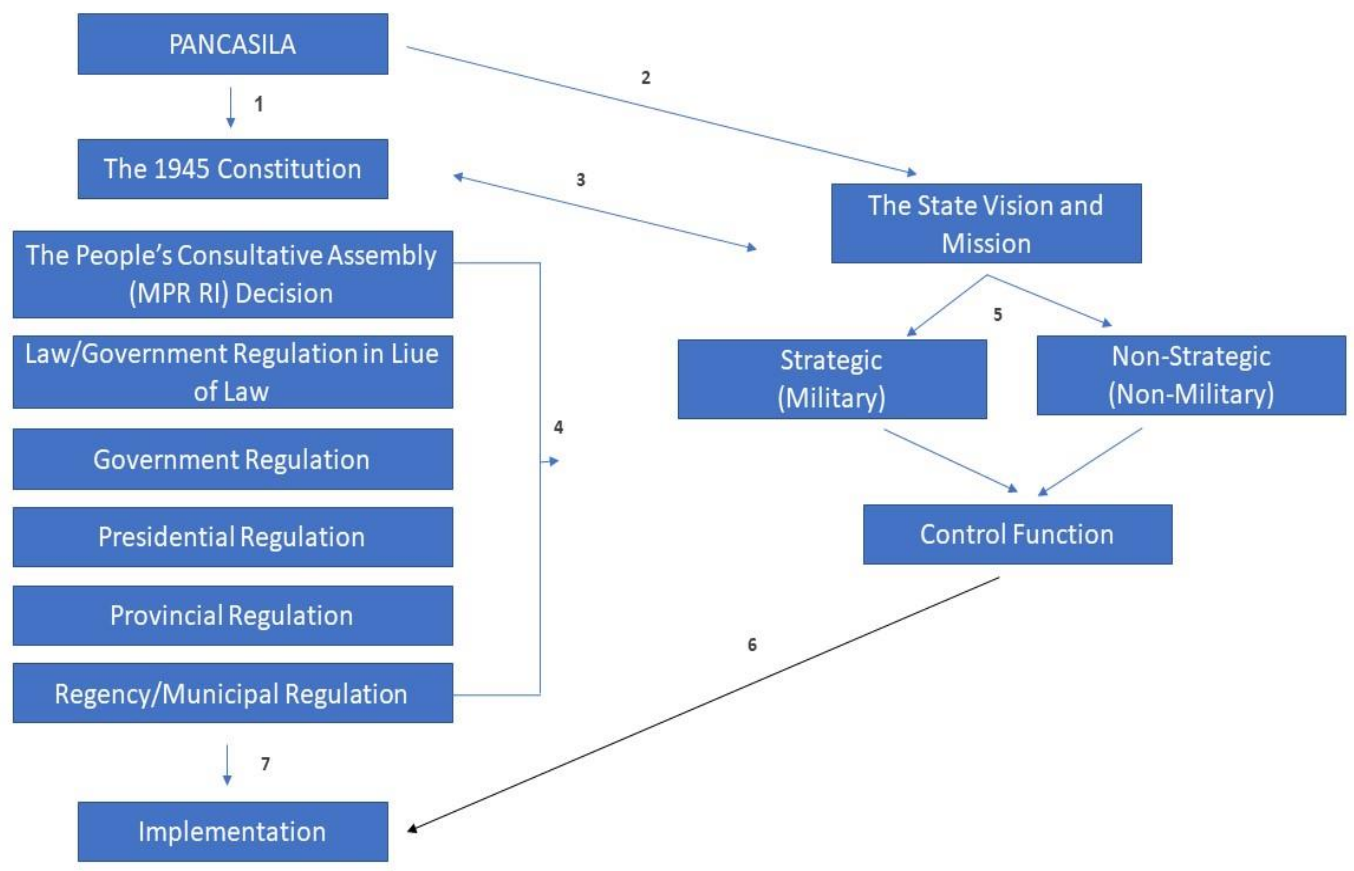

Explanation:

1 Pancasila is as the Grundnorm that the values are reflected to the 1945 Constitution. On fourth paragraph, there are nation ideals.

2 Pancasila contains values of Indonesian nation that become vision and mission of the nation, to achieve prosperity.

3 The 1945 Constitution declares the nation goals clearly on fourth paragraph. It means that the vision and mission of the nation are united on the 1945 Constitution Preamble that must be implemented by Indonesian nation.

4 As a Rechtsstaat, the vision and mission were written in the all laws and regulations based on the hierarchy of laws in law 12 of 2011 about formation of regulations

5 The vision and Mission of state on the national security and resilience concept are divided into two contexts including Military and Non-Military contexts

6 The function of the Military and Non-Military context is to protect the stability of the state.

7 In the implementation of laws and regulations, as a control so the stability is carried out based on the laws and regulations

The national security and resilience stability due to the control factors, in this stability there are smooth changes or sudden changes, called catastrophe jumps, the selection of control factors is a critical in maintaining the security of the Indonesian State. ${ }^{38}$

${ }^{38}$ Op.cit, Wan Usman et al, p 101 


\subsection{Constitutional Court As the ultimate interpreter of the constitution}

In connection with the Supreme Constitutional basically in civil society are Various interests to be served carefully by fellow community organized manner. ${ }^{39}$ Jimly asshiddiqie explained that the establishment of a constitutional court in each country has diverse backgrounds, in general it starts from a process of change in authoritarian power politics towards democracy, while the existence of a constitutional court is more to resolve conflicts between state institutions, because in the process a transition towards a democratic state is inevitable when conflicts arise between state institutions. ${ }^{40}$

Concerning the interpretation of the Constitution and acts as the only institution that has high authority to interpret the Constitution in 1945 (the ultimate interpreter of the constitution). The Constitutional Court is also called the guardian of democracy because it has the authority to decide election cases, in which the election is a representation of the implementation of justice. Besides, the constitutional Court also referred to the protector of citizen rights for Constitutional Court protects the constitutional rights of all citizens. ${ }^{41}$

The Constitutional Court is the State institution that included one of the institutions of judicial power which performs the functions of the judiciary in addressing the issues of constitutional authority of the 1945 Constitution. the Constitutional Court function which set the 1945 Constitution to the Constitutional Court, they are: 1) test the enactment law against Basic grounds; 2) decide upon disputes over the authority of state institutions whose body is granted by the Basic Law; 3) decide upon the dissolution of political parties; 4) decide upon disputes over the results of general elections; 5) give a decision on the opinion of the People's Representative Council of Indonesia that the President and / or Vice President are suspected of having committed violations of the law in the form of betrayal of the state, corruption, bribery, other serious crimes, or despicable acts, and / or no longer qualify as President and / or Vice President as referred to in the 1945 Constitution of the Republic of Indonesia. ${ }^{42}$

Of the many cases given to the Constitutional Court, the authorities in numbers 1 and 4 are the most proposed and decided cases by the Constitutional Court, cases of judicial review of the Constitution between 2003 and 2015 there were 859 cases, with details 89 being withdrawn by the applicant, 5 constitutional courts were not authorized, 203 applications were granted, the constitutional court rejected 297 cases, 251 applications were not accepted, and 13 were dropped. ${ }^{43}$ It based on Article 50 Number 24 of 2003 concerning the Constitutional Court but the constitutional court has cancelled this article. That is, when it no longer limits on judicial review under the authority of the Constitutional Court either law after the 1945 amendment and the law before the amendment. ${ }^{44}$

The Constitutional Court authority to hear at the first and last decision is final in terms of testing the test laws against the 1945 Constitution. Regarding Testing discourse-law rules

\footnotetext{
39 Jimly, Asshiddiqie, idea Social Constitution: The institutionalization of the Civil Society And Konstitusionalisasi Life, (Jakarta: Pustaka LP3ES, 2015), p 134

${ }^{40}$ Ni'matulhuda, Political State Administration of Indonesia; Study on Dynamics of Change Constitution 19456 (Yogyakarta: FH: UII Press, 2003) p.223

${ }^{41}$ Hamdan Zoelfa, "Mahkama Constitution and Future of Democracy Indonesia Legal State", In Some Aspects of Constitutional Law, Criminal Law, and Islamic law; Welcoming the 73 years of Prof. H. Muhammad Tahir Azhary, SH, Ed Hamdan Zoelva (Jakarta: Gold, 2012), p 53.

${ }^{42}$ Article 24C (Verse 1 and Verse 2)

${ }^{43}$ Annual Report 2015 of the Constitutional Court, p. 9

${ }^{44}$ Nurhidayatullah, (Journal Constitution, Volume 9, Number 1, March 2012, p 120
} 
(judicial review) or in the roof in the constitutional court, it is a perfect goal. But before it should examine how where the testing legislation (judicial review) to the Constitutional Court.

Testing of statutory regulations (Judicial review) initially contained in the third amendment to the Constitution of the Republic of Indonesia in regulating judicial power, including the regulation of the authority to test rights (toetsingrecth) possessed by the judge in conducting the review of the Law against The 1945 Constitution of the Republic of Indonesia is administered by the Constitutional Court. Whereas the authority to examine the statutory provisions under the Law on the Law is implemented by the Supreme Court. The use of the terms toetsingrecth and judicial review has the same meaning, namely the authority to test or examine. The difference is that in terms of the judicial review, it has explicitly been determined that the power is held by the executor of the court institution, namely the judge. For more details, here are the differences in both. ${ }^{45}$

The testing right (toetsingrecth) is the authority to evaluate the statutory provisions of the Constitution, while the judicial review assesses not only the laws and regulations but also the administrative action against the Constitution.

The testing right (toetsingrecth) of statutory regulations is not only owned by the judge, but also by other State institutions are given such authority based on statutory provisions. Whereas judicial review is only the authority of court judges in concrete cases in court. ${ }^{46}$

According to Sri Soemantri that the authority to examine the law is known, there are two items, namely formal testing (formele toetsingrecht) and material testing (materiele toetsingrecht). Formal testing is the authority to judge whether a legislative product is in accordance with procedures or not, and whether a power has the right to issue a precise regulation. Whereas material testing is the authority to investigate and assess whether statutory provisions is contradictory or not with a higher rule. ${ }^{47}$ The Authority test known laws are of two items, namely the formal testing (formele toetsingrecht) and material testing (materiele toetsingrecht). Then the formal testing is the authority to judge whether a legislative product is under procedures or not, and whether a power has the right to issue a specific regulation. Whereas material testing is the authority to investigate and assess whether statutory provisions is contradictory or not with a higher rule. ${ }^{48}$

Based on the purpose of testing of legislation (judicial review) to protect the rights of the people and uphold the 1945 Constitution, in accordance with the theme of the written discourse on testing one-legislation at the Constitutional Court is the legal basis for the people of Indonesia, because when there is snatching people's rights by the existence of laws and regulations, the Constitutional Court as the commander who is ready to be the protector of citizen right so that the people become more enlightened, because back to the functioning of the constitutional court as the ultimate interpreter of the constitution, and has a final decision.

\footnotetext{
${ }^{45}$ Fatmawati, Testing Rights (Toetsingrecth) Owned Justice System Law In Indonesia (Jakarta: Rajawali Press, 2005), p.5

${ }^{46}$ Ibid.p 11

${ }^{47}$ Sri Soemantri, Material Testing Rights In Indonesia (Bandunng: Alumni, 1997), p 47
} 


\section{Conclusion}

Security and resilience as a concept, Resilience and national security an essential concept in bringing the country of Indonesia forward, with globalization and technological development. Many threats of defense and security that come, especially those that are internal to the nation, asymmetrical warfare will be critical. It can divide the country if not immediately addressed, so that the concept of national defense and security becomes very important, because for the sake of the understanding of a safe and comfortable safe situation, but the circumstances This will not be achieved if the democracy and maturity of the people regarding the realization of the constitution have not been achieved, because the state of Indonesia is a state of law in accordance with article 1 paragraph (1) of the 1945 Constitution.

The relation between national security and security as the ideals of the nation really needs an umbrella to protects it, the Indonesian constitution as a derivative of the value of Pancasila is the legal basis in Indonesia, so that constitutional awareness is very important, and that people know their rights and obligations, constitutional awareness as the legal basis in Indonesia is big problem, the rule of law it is appropriate to educate people with an understanding of the law, in accordance with the legal concept of progressive Satjipto Rahardjo, that " law is not just building regulations, but also ideas, culture, and ideals" the theory of progressive law.

In this philosophical context, law functions to serve people, and not the other way around people who serve the law but humans must also be aware of the law for the realization of a safe, comfortable and peaceful state. If seen the State of Indonesia has been consistent with Article 1 paragraph one of the Constitution, so that in implementing government policies must be based on regulations, in accordance with laws and regulations in Indonesia. Therefore, the commander is the Constitutional Court because when there is a seizure of people's rights by a statutory regulation, the Constitutional Court as the commander is ready to be the protector of citizen rights. so that the people become more enlightened, because back to the function of the constitutional court as the ultimate interpreter of the constitution, and has a final decision.

\section{References}

[1] Ahmad Zubaidi Kaelan, 2007 Kewarganegaraan Study And Teaching Yogyakarta: Paradigm.

[2] Bambang, Pranowo, 2010, Multidimensional National Resilience (Jakarta: Reader Alvabet.

[3] Berkowitz, Morton, And Bock, PG, 1965, Eds. American National Security. New York: Free Press.

[4] Dand Hornerr, 1992, Strategic Studies In Changing World. The Australian University Canbera.

[5] Fatmawati, 2005, Toetsingrecth Owned by Judges in the Indonesian Legal System (Akarta: Rajawali Press.

[6] H. Abudaud Busaroh, 2010, State Science. Jakarta, Bumi Aksarai.

[7] Hermann, Charles; 1977 " Are The Dimensions And Implications Of National Security Changing, Mershon Center Quaterly Report 3, No. 1 Autumn

[8] Hamdan Zoelfa, 2012 " Constitutional Court and the Future of Indonesia's Democratic Law State ", In Some Aspects of State Administration Law, Criminal Law, and Islamic Law; Welcoming 73 Years of Prof. H. Muhammad Tahir Azhary, SH, Ed Hamdan Zoelva Jakarta: Kencana.

[9] J imly, A sshi dd i q ie, 2015, the idea of Social Constitution: The institutionalization of the Civil Society And constitutional of Life, J a k a r ta: Library LP3ES.

[10] Annual Report of the Constitutional Court 2015

[11] Ni'matulhuda, 2003 Politics of Indonesian State Administration; Study on the Changing Dynamics of the 1945 Constitution Yogyakarta: FH: UII Press. 
[12] Nurhidayatullah, 201, (Journal of the Constitution, Volume 9, Number 1, March 2012)

[13] Sekretariat Security Council of the National 2010, National Security, Concept and Security System to Indonesia, Jakarta: Secretariat of the Security Council of the National

[14] Idonesia Law Figure Series Collection of Views Articles, 2011, Sacipto Rahardjo and Progressife Law Urgence and Criticism, Jakarta: Epistema Institute.

[15] Sony, Soemarsono, 2001 Public Policy Theory: Human Resource Economics Yogyakarta: Graha Science.

[16] Sri Soemantri, 1997 Right to Test Material in Indonesia Bandung: Alumni.

[17] Wan Usman et al., 2003, Endurance of the Nation, Jakarta: National Library.

[18] Nugraha, A \& Loy, N 2013, Population Development to Strengthen National Resilience in the Face of Asymmetric War Threats, (Directorate of Population Impact Analysis, BKKBN, Jakarta, ISBN 978-602-7584-35

[19] Law Number 32 of 2004 concerning Indonesian National Armed Forces.

[20] Law Number 2 of 2002 concerning the Indonesian National Police. 